\title{
Recent Advances and Developments in Nanoparticles/
}

\section{Nanocomposites as Nanoadsorbent for Adsorptive Removal of}

\section{Lead in Wastewater: A Review}

\author{
Shehu $\mathrm{Z}^{1 *}$ and Lamayi DW1 \\ Department of Chemistry, Faculty of Science, Gombe State University, Nigeria \\ *Corresponding author: Zaccheus Shehu, Chemistry department, Faculty of Science, \\ Gombe State University, Nigeria, Email: zaccheusshehu@gmail.com
}

\section{Review Article \\ Volume 4 Issue 3}

Received Date: June 24, 2019

Published Date: July 08, 2019

DOI: $10.23880 /$ nnoa- 16000165

\section{Abstract}

Wastewater and or water contamination due to Lead is of significant occupational and environmental concern because of the possibility of Lead to enter the food chain. There are numerous adsorbent used in adsorption of Lead in wastewater. This includes agricultural biomass, industrial sludge as well as activated carbon prepared from these materials. Recently, nanoparticles and nanocomposites have been synthesized and applied as nanoadsorbent for Lead removal from solution. This review highlights synthesis, characterization and application of nanoadsorbents for Lead adsorption in wastewater.

Keywords: Adsorption; Nanoadsorbent; Nanoparticles/Nanocomposites; Lead; Wastewater

Abbreviations: WHO: World Health Organisation; SEM: Scanning Electron Microscopy; FTIR: Fourier Transform Infra-Red Spectroscopy; TEM: Transmission Electron Microscopy; IR: Infrared; NIR: Near-Infrared; UV: Ultraviolet-Visible; TGA: Thermal Gravimetric Analysis; XRD: X-Ray Diffraction; CMC: Carboxy Methyl Chitosan; ED: Eleocharis Dulcis.

\section{Introduction}

Lead contamination is becoming a serious issue of concern around the world due to the increase in the use and processing to meet the needs of the rapidly growing population. In general, all components of the environments such as soil (land), water, and air are affected by Lead pollution. Land (soil) contamination due to Lead comes from the following sources and activities such as industrial activities, mine tailings, disposal of high metal wastes, leaded gasoline and paints, land application of fertilisers, animal manures, sewage sludge, pesticides, wastewater irrigation, coal combustion residues and spillage of petrochemicals lead to soil contamination by heavy metals. There are different ways through which Lead present risks to humans, animals, plants and ecosystems as a whole. For example; direct ingestion, absorption by plants, food chains, consumption of contaminated water and alteration of soil $\mathrm{pH}$, porosity, colour and its natural chemistry which in turn impact on the soil quality $[1,2]$. Industrialization and urbanisation are two main sources of water contamination due Lead. Lead is transported by runoff from industries, municipalities and urban areas. And the Lead end up accumulating in the soil and sediments of water bodies [3]. Lead can be found in traces in water sources and still be very toxic and impose serious health problems to humans and other ecosystems. Thus, the contamination of water by Lead actually affects all living organisms. Air pollution due to Lead has their sources from natural processes and anthropogenic activities. Natural processes release particulate matters containing Lead into air such 


\section{Nanomedicine \& Nanotechnology Open Access}

as dust storms, soil erosion, volcanic eruptions and rock weathering, while anthropogenic activities are more industrial and transportation related [4,5].

Severe damages to the nervous system, kidney, reproductive system, brain, liver cause illness or death has been reported due to Lead poisoning. And severe exposure to lead has been connected with stillbirths, abortion, sterility and neonatal death [2-9]. Thus, the permissible limit recommended by the World Health Organisation (WHO) is (3-10 $\mu \mathrm{g} / \mathrm{L})$ in drinking water [10]. Therefore removal of lead in effluent and water remains crucial. Different methods are employed for the treatment of industrial effluents containing Lead. These important methods are chemical precipitation, ion exchange, electrodialysis and adsorption etc. But Adsorption technique being very economical, simple, versatile and effective has been widely preferred for the removal of Lead from aqueous environment [11-30].

Nanotechnology can be used to monitor water quality in real time and even remove pathogens (diseases such as cholera) and inorganic pollutants (toxic heavy metals)as well as organic pollutants from water, making it possible for even the most remote communities to have safe, clean drinking water. This can be achieved with the aid of various nanoadsorbents obtained from different nanoparticles and nanocomposites. Therefore, this article gives a brief overview on application of nanoparticles/ nanobiocomposites for the removal of Lead from aqueous environment.

\section{Adsorption}

Adsorption is the adhesion of ions, or molecules, atoms, from a liquid, gas or dissolved solids to a surface. The solids that are used to adsorb gases or dissolved substances are called adsorbents and the adsorbed molecules are referred as the adsorbate. Adsorption creates a film of adsorbate on the surface of adsorbent. It is a surface phenomenon that depends upon specific surface area, number of site available, porosity of the adsorbent and numerous interactions types. No formation of harmful substances is associated with adsorption process [31-36].

\section{Nanoadsorbent Fabrication}

There are two main approaches to synthesize nanoadsorbent. One is top-down approach and another is the bottom-up approach. All other classifications fall on these two approaches. The descriptions of these approaches are as followed.

\section{Top-Down Approach}

As the name suggests, the top-down approach means from top (larger) to bottom (smaller). This approach is similar to making a statue made of stone. As in making of a statue, a bulk or big piece of stone is taken, similarly in top-down approach; a bulk piece of material is taken. Then carving and cutting is done until desired shape is achieved. Examples include chemical etching, grinding, ball milling, thermal/laser ablation and sputtering [37].

\section{Bottom-Up Approach}

As the name suggests, the bottom-up approach means from bottom (smaller) to top or up(larger). In this technique, a nanometric structure is taken then using methods of assembly or self assembly, a mechanism is developed which is larger than where it is started. Chemical/Electrochemical, precipitation, vapour deposition, atomic/molecular condensation, sol gel processes, spray pyrolysis, laser pyrolysisand aerosol pyrolysis as well as green synthesis(such as using bacteria, fungi, plant extracts etc) are examples of bottoup approach [33].

\section{Nanoadsorbent Characterization}

The most common techniques used in characterization of nanoadsorbent based on these studies are Scanning Electron Microscopy (SEM), Transmission Electron Microscopy (TEM), X-Ray Diffraction, Fourier transform infra-red spectroscopy (FTIR), Ultraviolet-visible spectroscopy and Thermal gravimetric analysis [31-54].

\section{Fourier Transform Infra-Red (FTIR)}

Fourier Transform Infrared (FTIR) spectroscopy is a powerful tool for identifying types of chemical bonds in a molecule by producing an infrared absorption spectrum that is like a molecular fingerprint. Infrared (IR) spectroscopy is one of the most common spectroscopic techniques used by organic and inorganic chemists. Simply, it is the absorption measurement of different IR frequencies by a sample positioned in the path of an IR beam. The main goal of IR spectroscopic analysis is to determine the chemical functional groups in the sample. Different functional groups absorb characteristic frequencies of IR radiation. Using various sampling accessories, IR spectrometers can accept a wide range of sample types such as gases, liquids, and solids. Thus, IR 


\section{Nanomedicine \& Nanotechnology Open Access}

spectroscopy is an important and popular tool for structural elucidation and compound identification [39].

\section{Ultraviolet-Visible (UV-Vis) Spectroscopy}

Ultraviolet-visible spectroscopy or ultraviolet-visible spectrophotometry (UV-vis or UV/vis) refers to absorption spectroscopy in the ultravioletvisible spectral region. This means it uses light in the visible and adjacent (near-UV and nearinfrared (NIR)) ranges. The absorption in the visible range directly affects the perceived color of the chemicals involved. In this region of the electromagnetic spectrum, molecules undergo electronic transitions [39].

\section{Thermal Gravimetric Analysis (TGA)}

Thermo gravimetric analysis or thermal gravimetric analysis (TGA) is a method of thermal analysis in which changes in physical and chemical properties of materials are measured as a function of increasing temperature (with constant heating rate), or as a function of time (with constant temperature and/or constant mass loss). TGA can provide information about physical phenomena, such as second-order phase transitions, including vaporization, sublimation, absorption, adsorption, and desorption. Likewise, TGA can provide information about chemical phenomena including chemisorptions, desolvation (especially dehydration), decomposition, and solid-gas reactions (e.g., oxidation or reduction). TGA is commonly used to determine selected characteristics of materials that exhibit either mass loss or gain due to decomposition, oxidation, or loss of volatiles (such as moisture) [39].

\section{X-Ray Diffraction (XRD)}

The discovery of X-rays in 1895 enabled scientists to probe crystalline structure at the atomic level. X-ray diffraction has been in use in two main areas, for the fingerprint characterization of crystalline materials and the determination of their structure. Each crystalline solid has its unique characteristic X-ray powder pattern which may be used as a "fingerprint" for its identification. Once the material has been identified, X-ray crystallography may be used to determine its structure, i.e. how the atoms pack together in the crystalline state and what the inter atomic distance and angle are etc. X-ray diffraction is one of the most important characterization tools used in solid state chemistry and materials science. We can determine the size and the shape of the unit cell for any compound most easily using X-ray diffraction [39].

\section{Transmission Electron Microscopy (TEM)}

TEM is a powerful and unique technique for structure characterization. The most important application of TEM is the atomic-resolution real-space imaging of nanoparticles. TEM is unique in identifying and quantifying the chemical and electronic structure of individual nanocrystals. Electron energy-loss spectroscopy analysis of the solid-state effects and mapping the valence states are even more attractive. In situ TEM is demonstrated for characterizing and measuring the thermodynamic, electric, and mechanical properties of individual nanostructures, from which the structure-property relationship can be registered with a specific nanoparticle/structure [39].

\section{Scanning Electron Microscopy (SEM)}

The Scanning Electron Microscope images of the surface of the sample under measurement by scanning it with a high-energy beam of electrons. SEM gives topographical as well as chemical composition [39].

\section{Application of Nanoadsorbent for Lead Adsorption in Wastewater}

Table 1 provides the summery of numerous nanoadsorbents used for removal of Lead in wastewater. The nanoadsorbent is used either as a nanoparticle or its combination to another nanoparticle or other materials (to give nanocomposite). Montmorillonite-silica nanocomposite was synthesized and found to have higher percentage removal of $99.99 \%$ and adsorption capacity of $132.802 \mathrm{mg} / \mathrm{g}$ [40]. The removal efficiency of Lead by some iron base nanoadsorbent was widely investigated by different authors. Magnetite -Dowex 50WX4 (MagDow) nanocomposite was synthesized, characterized and tested for heavy metal ions (Cr (VI), $\mathrm{Ni}^{2+}, \mathrm{Cu}^{2+}, \mathrm{Cd}^{2+}$ and $\mathrm{Pb}^{2+}$ ) removal. Transmission Electron Microscopy (TEM) results showed the formation of nanoparticles of size ranging from 2-10 $\mathrm{nm}$. Adsorption experiments in batch mode were conducted using the developed nanocomposite. Different factors affecting the adsorption process like reaction time, initial metals concentration, $\mathrm{pH}$ and adsorbent dose were investigated to optimize the operation conditions for the composite nanoparticles. The adsorption capacity of the composite was found to increase by time and adsorption attains equilibrium in 30 min. The desorption efficiency for different metals used was found to be $96 \%$ of the prepared adsorbent suggest that the prepared composite is as an effective tool for removal of Lead [18]. Vazquez-Olmos, et al. [26] reported 


\section{Nanomedicine \& Nanotechnology Open Access}

the adsorption of $\mathrm{Pb}(\mathrm{II})$ from aqueous solution using $\mathrm{MFe}_{2} \mathrm{O}_{4}$ nanoferrites ( $\mathrm{M}=\mathrm{Co}, \mathrm{Ni}$, and $\mathrm{Zn}$ ). Nanoferrite samples were prepared via the mechanochemical method and were characterized by X-ray powder diffraction (XRD), Fourier transform infrared spectroscopy (FTIR), micro-Raman, and vibrating sample magnetometry (VSM). XRD analysis confrms the formation of pure single phases of cubic ferrites with average crystallite sizes of 23.8, 19.4, and $19.2 \mathrm{~nm}$ for $\mathrm{CoFe}_{2} \mathrm{O}_{4}, \mathrm{NiFe}_{2} \mathrm{O}_{4}$, and $\mathrm{ZnFe}_{2} \mathrm{O}_{4}$, respectively. Only $\mathrm{NiFe}_{2} \mathrm{O}_{4}$ and $\mathrm{ZnFe}_{2} \mathrm{O}_{4}$ samples show super paramagnetic behaviour at room temperature, whereas $\mathrm{CoFe}_{2} \mathrm{O}_{4}$ is ferromagnetic. Kinetics and isotherm adsorption studies for adsorption of $\mathrm{Pb}$ (II) were carried out. A pseudo-second-order kinetic describes the sorption behaviour. The experimental data of the isotherms were well fitted to the Langmuir isotherm model. The maximum adsorption capacity of $\mathrm{Pb}(\mathrm{II})$ on the nanoferrites was found to be $20.58,17.76$, and $9.34 \mathrm{mg} \cdot \mathrm{g}^{-1}$ for $\mathrm{M}=\mathrm{Co}, \mathrm{Ni}$, and $\mathrm{Zn}$, respectively. Shiralipour, et al. [22] studied the adsorption of Lead $(\mathrm{Pb})$ by zero-valent iron nanoparticle in contaminated water. Four samples, each from different water sources like Well water (Shushtar, Iran), Karoon River (Ahvaz, Iran), Caspian Sea (northern Iran) and Persian Gulf (southern Iran) were collected. The elapsed time for quantitative removal of $\mathrm{Pb}$ ions was two minutes. The adsorption of $\mathrm{Pb}$ ions on ZVINPs was well followed by the Langmuir model. The maximum adsorption amounts of $\mathrm{Pb}$ ions on ZVINPs were 96.5 $\mathrm{mg} / \mathrm{g}$. In other report, Magnetic chitosan (CS) and carboxymethylchitosan (CMC) Nanocomposites have been synthesized by a simple one-step chemical coprecipitation method. The nanoparticles were assessed for the removal of $\mathrm{Pb}^{2+}$ ions from aqueous solution. Kinetic and thermodynamic models were used to describe and understand the adsorption process of the ions onto the nanomaterial. The interactions between the ions and the biopolymer-based composites are reversible, which means that the nanoparticles can be regenerated in weakly acidic or EDTA containing solution without losing their activity and stability for water cleanup applications. The maximum adsorption capacity of Magnetic chitosan (CS) and carboxymethylchitosan (CMC) Nanocomposites were found to be 141 and $243 \mathrm{mg} / \mathrm{g}$ respectively [27]. Giraldo, et al. [30] reported that $\mathrm{Fe}_{3} \mathrm{O}_{4}$ magnetic nanoparticles were synthesized by co-precipitation method. The structural characterization showed an average nanoparticle size of $8 \mathrm{~nm}$. The synthesized $\mathrm{Fe}_{3} \mathrm{O}_{4}$ nanoparticles were tested for the treatment of synthetic aqueous solutions contaminated by metal ions, i.e. $\mathrm{Pb}(\mathrm{II})$. Various factors influencing the adsorption of metal ions, e.g., $\mathrm{pH}$, temperature, and contacting time were investigated to optimize the operating condition for the use of $\mathrm{Fe}_{3} \mathrm{O}_{4}$ nanoparticles as adsorbent. $\mathrm{Pb}$ (II) adsorption efficiency gradually increases from $75.7 \%$ to $92.3 \%$ when the $\mathrm{pH}$ increases from 2 to 7 . The maximum adsorption capacity of $\mathrm{Fe}_{3} \mathrm{O}_{4}$ nanoparticles in the investigated conditions was $0.180 \mathrm{mmol} \mathrm{g}^{-1}$. The study of biocomposite nanoparticles of Eleocharis dulcis (ED) as potentials biosorbent to reduce the concentration of lead (II) ion containing Sasirangan textile industry wastewater was investigated [50]. Batch experiments were carried out to considering the kinetic of biosorption of lead onto the adsorbent, evaluating the effects of lead ion equilibrium concentration, equilibrium $\mathrm{pH}$, and temperature on the adsorption of lead (II). Kinetic data of lead (II) biosorption onto EDB and EDB-MH revealed that equilibrium time was reached within $2 \mathrm{~h}$, and the isotherm data showed that the Langmuir maximum adsorption capacity of the EDB-M and EDB-MH at pHe of $6 \pm 0.2$, room temperature were $150.43 \mathrm{mg} / \mathrm{g}$ and 180.92 $\mathrm{mg} / \mathrm{g}$, respectively [50].

Das, et al. [53] developed a simple approach for the biosynthesis of iron oxide nanoparticles $\left(\mathrm{Fe}_{3} \mathrm{O}_{4}\right.$-NPs) using Trigonella foenum-graecum leaf extract and used it for possible removal of lead from aqueous solution and wastewater. SPR peak at $248 \mathrm{~nm}$ confirms the bioreduction and formation of $\mathrm{Fe}_{3} \mathrm{O}_{4}$-NPs. The shape and size of the nanoparticles were evaluated by SEM equipped with EDX, TEM, XRD. The particles were found crystalline and roughly spherical in shape with an average size range of 51.6-215.7 nm. The possible biomolecules participated in the biosynthetic reaction which was confirmed by FTIR spectrum. These nanostructured particles were used for batch adsorption study for the removal of lead ions. The effects of various physical and chemical parameters like $\mathrm{pH}$, contact time, adsorbent dosage and initial concentrations on the removal of heavy metals were studied on removal efficiency. The maximum lead (II) ions removal uptake was found $93 \pm 0.13 \%$ at $\mathrm{pH} 6.0$ with $0.4 \mathrm{~g}$ of these nanoparticles within $60 \mathrm{~min}$ of contact time. Desorption studies indicated that the regenerated nanoparticles retained its original metal adsorption efficiency. Results showed that these regenerable iron oxide nanoparticles can be used as nano-adsorbent for removal of heavy metals from environmental waste due to its high metal uptake capacity. According to Namavari


nanoparticles supported by Aloe vera shell ash in removing $\mathrm{Pb}$ from aqueous environments was studied. The adsorbent was characterized by several methods, including x-ray diffraction (XRD), scanning electron 


\section{Nanomedicine \& Nanotechnology Open Access}

microscopy (SEM), and Fourier transform infrared spectroscopy (FT-IR). Then, the potential of Aloe vera

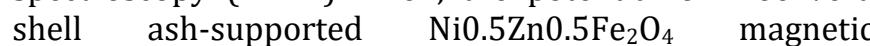
nanoparticles to adsorb $\mathrm{Pb}$ (II) was investigated. To determine the amount of lead absorbed by this adsorbent, different pHs $(2,4,5$, and 6), adsorbent doses (0.01-0.40 g), $\mathrm{Pb}$ concentrations $(5,10,20,30,40,50,60,80,100$, $200,300$, and $600 \mathrm{mg} / \mathrm{L})$, and exposure times $(0,5,10,15$, $20,30,40,50$, and 60 minutes until reaching equilibrium) were tested using an atomic absorption spectrometer (Varian-AA240FS). Residual concentrations of $\mathrm{Pb}$ were read. The results show that a time of 15 minutes, $\mathrm{pH}$ value of 9 , and adsorbent dose of $0.2 \mathrm{~g}$ are the optimum conditions for $\mathrm{Pb}$ (II) removal by this adsorption process. Increase in the initial concentration of $\mathrm{Pb}$ (II) from 5 to $600 \mathrm{mg} / \mathrm{L}$ decreased removal efficiency from $98.8 \%$ to $73 \%$. The experimental data fit well into the Freundlich isotherm model $(\mathrm{R} 2=0.989)$.

Haerizade, et al. [44] reported thatToxic lead ions was removed efficiently from water by a newly fabricated, magnetically recyclable, antibacterial nano- $\mathrm{Ag} / \gamma^{-}$ $\mathrm{Fe}_{2} \mathrm{O}_{3} @ G O a d s o r b e n t$, at ambient and the physiological $\mathrm{pH}=7$. The adsorption depends on the adsorbent dosage, initial $\mathrm{Pb}(\mathrm{II})$ concentration, $\mathrm{pH}$ and the contact time. The optimum removal efficiency of the leadion is found to be $93.1 \%$ with a dosage rate of $20 \mathrm{mg} / \mathrm{L}$, in 40 minutes, at $\mathrm{pH}$ 5 (to 14). Equilibrium data fits well with the Langmuir and Freundlich models with a maximum adsorption capacity of $90.91 \mathrm{mg} / \mathrm{g}$ of $\mathrm{Pb}(\mathrm{II})$ per $20 \mathrm{mg} / \mathrm{L}$ of $\mathrm{Ag} / \gamma^{-}$ Fe203@GO. The removal/uptake mechanism involves interaction between $\mathrm{Pb}(\mathrm{II})$ and the oxide/hydroxyl layer around $\mathrm{Ag} / \gamma-\mathrm{Fe}_{2} \mathrm{O}_{3} @ \mathrm{rGO}$, in the contaminated water medium. Moezzi, et al. [45] stated that, a reduction method in solution phase was applied to synthesize the iron nanoparticles and used in lead removal. Afterwards, the size of the synthesized particles was confirmed by Scanning Electron Microscopy. It is worth noting that the nanoparticle dose-variations were examined in the range of $0.02-0.5 \mathrm{mg}$ while $\mathrm{pH}$ and exposure time were respectively investigated in the ranges of 3-11 and 1-40 min. Meanwhile, the removal efficiency of various concentrations of lead ions were evaluated in the range of $1-50 \mathrm{mg} / \mathrm{l}$. The results indicated that the best removal efficiency $(92.5 \%)$ occurred in the concentration range of 1 to $40 \mathrm{mg} / \mathrm{l}$ for a dose of $0.1 \mathrm{mg}$ nanoparticles. By increasing concentration of lead ions to $50 \mathrm{mg} / \mathrm{l}$, the optimum dose was achieved in $0.2 \mathrm{mg}$. Improved removal was observed with increasing exposure time up to 10 minutes while no improvement was recorded for exposure times of 20 minutes or longer. The results confirmed the effectiveness of synthesized iron nanoparticles in removing lead ions from aquatic solution.

Other nanoparticles apart from iron based nanoparticles were also used in removal of Lead in solution. Thus, Composite based on eucalyptus leaf and polyaniline (EL-PANi) was prepared by chemical polymerization method. It showed that the function groups belonging to polyaniline and eucalyptus leaf were found through IR analysis and the nanostructure of composite was explained by SEM images. The adsorption of $\mathrm{Pb}^{2+}$ was carried out onto composite in aqueous solution via varying $\mathrm{pH}$, contact time, and its initial concentration. The experimental adsorption data fitted well into Freundlich adsorption isotherm model (R2 0.99). The adsorption process followed pseudo-second order kinetic with $\mathrm{R} 2 \sim 1$. The maximum adsorption capacity qmax of $\mathrm{Pb} 2+$ onto that composite was 172.41 $\mathrm{mg} / \mathrm{g}$ by Langmuir equation and Freundlich constant KF was $53.75 \mathrm{mg} / \mathrm{g}$ by Freundlich one [20]. Poursani, et al. [21] reported that nano-TiO2 particles were synthesized by sol-gel method. The synthesized nanoparticles were characterized by Fourier Transform Infrared (FT-IR), Xray diffraction (XRD), Transmission electron microscope (TEM) and Brunauer-Emmett-Teller (BET). The results showed that the average size of $\mathrm{TiO}_{2}$ nanoparticles and their specific surface area were 21.1 nanometer and 55.35 $\mathrm{m}^{2} / \mathrm{gr}$, respectively. The effects of several variables such as adsorbent weight, $\mathrm{pH}$ and contact time on lead ions adsorption were studied in batch experiments and finally the optimum conditions for lead ions adsorption by synthesized nano- $\mathrm{TiO}_{2}$ were obtained. The results showed that the synthesized nano $\mathrm{TiO}_{2}$ had a good capacity to adsorb lead ion. The kinetic data were described by pseudo-first and second-order models. Freundlich and Langmuir isotherm models were used for the analysis of equilibrium data, and results showed that the Langmuir model was suitable for describing the equilibrium data of lead ion adsorption by nano $\mathrm{TiO}_{2}$. Using the Langmuir isotherm, the maximum sorption capacity of $\mathrm{Pb}^{2+}$ was estimated to be $7.41(\mathrm{mg} / \mathrm{g})$ at $25^{\circ} \mathrm{C}$. Dargahi, et al. [29] investigated the efficiency of magnesium oxide nanoparticles (MON) in vitro for the removal of lead (II) and chromium (VI) from aqueous environments. The effects of various parameters such as contact time (15 to $280 \mathrm{~min}), \mathrm{pH}(3,5,7$ and 9), the initial concentration of lead/chromium $(10,20,30.40$ and $50 \mathrm{mg} / \mathrm{L})$, absorbent dose $(0.3,0.5$ and $0.8 \mathrm{~g} / \mathrm{L}$ ), and shaking speed (150 to 350 rpm) was investigated. The parameters were optimized by varying one parameter at a time and keeping other parameters constant. The maximum removal efficiency of 


\section{Nanomedicine \& Nanotechnology Open Access}

MON for lead (II) and chromium (VI) was achieved at contact time $280 \mathrm{~min}, \mathrm{pH} \mathrm{9}$, initial concentration of lead/chromium $10 \mathrm{mg} / \mathrm{L}$, adsorbent dose $0.8 \mathrm{~g} / \mathrm{L}$, and shaking speed $250 \mathrm{rpm}$. The results also indicated that MON convert the $\mathrm{Pb}^{2+}$ to $\mathrm{Pb}^{0}$ and $\mathrm{Cr}^{6+}$ to $\mathrm{Cr}^{3+}$ during the removal process. The adsorption of lead (II) and chromium (VI) follows the Langmuir isotherms, therefore the adsorption was of a physical nature. Zadeh, et al. [16] reported that $\mathrm{Al}_{2} \mathrm{O}_{3}-\mathrm{SiO}_{2}$ nanoparticle was an effective adsorbent for removal of Lead in solution. Thus in the study, $\mathrm{Al}_{2} \mathrm{O}_{3}-\mathrm{SiO}_{2}$ nanoparticle by the weight ratio 50:50 of $\mathrm{Al}_{2} \mathrm{O}_{3} / \mathrm{SiO}_{2}$ was studied to obtain an effective adsorbent for the removal of $\mathrm{Pb}(\mathrm{II})$ ion from aqueous solution. In this research, a simple ,economic and environment-friendly method has been presented for the preparation of $\mathrm{Al}_{2} \mathrm{O}_{3}-\mathrm{SiO}_{2}$ nanoparticle via sol-gel method. The structure of prepared nanoparticle was characterized by FTIR, BET, SEM, XRD and EDX. The SEM analysis shows that the average size of the particles is about $40 \mathrm{~nm}$ and BET analyzer data shows that the average pore size and surface area of the material are $4.9522 \mathrm{~nm}$ and 163.58 $\mathrm{m}^{2} / \mathrm{g}$ respectively. Various factors influence the adsorption of $\mathrm{Pb}(\mathrm{II})$ ion such as contact time, the amount of adsorbent and $\mathrm{pH}$ value of the solutions which were investigated by batch experiments. The adsorption was fast; nearly $98 \%$ of $\mathrm{Pb}$ (II) could be removed within 10 min. The equilibrium data was applied to Langmuir, Freundlich, Tempkin, isotherm models. Adsorption isotherm fitted well by Freundlich model. The maximum adsorption capacity is $37.03 \mathrm{mg} / \mathrm{g}$ at $\mathrm{pH}=8.0$. Kinetics data revealed that the overall adsorption process followed pseudo-second-order. This study proves that $\mathrm{Al}_{2} \mathrm{O}_{3}-\mathrm{SiO}_{2}$ nanoparticle was an effective adsorbent for removal of $\mathrm{Pb}(\mathrm{II})$ ion from aqueous solutions.

Therefore, from Table 1 the optimum conditions for Lead removal using various nanoadsorbents were found in the following ranges; $76-99.99 \%$ removal, $7-976 \mathrm{mg} / \mathrm{g}$ adsorption capacity, $\mathrm{pH}$ of 2-11, 0.001-2.5 g adsorbent and 1-280 minutes. These suggest that nanoadsorbents are promising adsorbents for environmental protection application especially for Lead remediation.

\begin{tabular}{|c|c|c|c|c|c|c|}
\hline Nanoadsorbent type & $\begin{array}{l}\text { Adsorbent, } \\
\mathrm{g}\end{array}$ & $\mathbf{p H}$ & $\begin{array}{c}\text { Time, } \\
\text { min. }\end{array}$ & $\begin{array}{c}\text { Adsorption } \\
\text { capacity, } \mathrm{mg} / \mathrm{g}\end{array}$ & $\begin{array}{c}\% \\
\text { Rem. }\end{array}$ & Ref. \\
\hline PVK-GO Polymer nanocomposite & 0.001 & 7 & 90 & 887.98 & 97 & [8] \\
\hline $\begin{array}{l}\text { Poly(amidoamine)-graft-poly(methyl } \\
\text { acrylate) magnetic NC }\end{array}$ & 0.01 & $\begin{array}{l}\text { 6- } \\
\text { May }\end{array}$ & 30 & 310 & & [9] \\
\hline CAZn, activated carbon & \multirow{3}{*}{0.2} & \multirow{3}{*}{6} & 80 & 72.62 & & \multirow{3}{*}[10]{} \\
\hline CAH, activated carbon & & & 80 & 58.62 & & \\
\hline CAK, activated carbon & & & 100 & 12.16 & & \\
\hline $\mathrm{CuO}$ & \multirow{2}{*}{0.1} & \multirow{2}{*}{3.5} & \multirow{2}{*}{30} & & 84.162 & \multirow{2}{*}[11]{} \\
\hline $\mathrm{Fe}_{3} \mathrm{O}_{4}$ nanoparticles & & & & & 88.028 & \\
\hline $\begin{array}{l}\text { Magnetite-Dowex 50WX4 } \\
\text { nanocomposite }\end{array}$ & 0.5 & 6.5 & 30 & 380 & 97 & [14] \\
\hline $\begin{array}{l}\text { eucalyptus leaf and polyaniline (EL- } \\
\text { PANi) composite }\end{array}$ & 0.1 & 6 & 10 & 172.41 & 95 & {$[16]$} \\
\hline $\mathrm{TiO}_{2}$ nanoparticle & 0.2 & 6 & 240 & 7.41 & 90 & [17] \\
\hline Zero-valent iron nanoparticles & 0.2 & 2 & 2 & 96.5 & 99 & [18] \\
\hline NC-MC composite & \multirow[t]{2}{*}{ 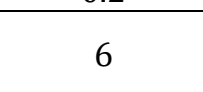 } & \multirow{2}{*}{6} & & 907 & 76 & \multirow{2}{*}{ [19] } \\
\hline NC-KC composite & & & & 976 & 85 & \\
\hline Chromium doped $\mathrm{NiO}$ nanoparticles & 0.15 & 9 & 45 & & 99.6 & {$[20]$} \\
\hline $\mathrm{CoFe}_{3} \mathrm{O}_{4}$ & \multirow{3}{*}{0.01} & \multirow{3}{*}{2} & \multirow{3}{*}{60} & 20.58 & & \multirow{3}{*}[22]{} \\
\hline $\mathrm{NiFe}_{3} \mathrm{O}_{4}$ & & & & 17.76 & & \\
\hline $\mathrm{ZnFe}_{3} \mathrm{O}_{4}$ & & & & 9.34 & & \\
\hline Cs mangnitite & & & \multirow{3}{*}{5} & 141 & & \multirow{3}{*}[23]{} \\
\hline CMC magnetite & & & & 243 & & \\
\hline nanoparticles & & & & & & \\
\hline MgO nanoparticle & 0.8 & 9 & 280 & 21.78 & 94.78 & {$[25]$} \\
\hline $\mathrm{Fe}_{2} \mathrm{O}_{4}$ & 0.2 & 7 & 2 & 0.189 & 92.3 & {$[26]$} \\
\hline Montmorillonit-silica nanocomposite & 0.3 & 5 & 40 & 132.802 & 99.99 & [36] \\
\hline
\end{tabular}

Shehu Z and Lamayi DW. Recent Advances and Developments in Nanoparticles/ Nanocomposites as Nanoadsorbent for Adsorptive Removal of 


\section{Nanomedicine \& Nanotechnology Open Access}

\begin{tabular}{|c|c|c|c|c|c|c|}
\hline CS NP-modified $\mathrm{MnO}_{2}$ & 2 & 6 & 3 & 102.5 & 93 & [37] \\
\hline $\mathrm{Ni} 0.5 \mathrm{Zn} 0.5 \mathrm{Fe}_{2} \mathrm{O}_{4}$ magnetic nanoparticles & 0.2 & 2 & 15 & 47.2 & 98.8 & [38] \\
\hline Polyaniline (PANI) nanocomposites & 0.4 & 4 & 120 & 7 & 90 & [39] \\
\hline Ag/ $\gamma$-Fe203@GO nanocomposite & 0.02 & 5 & 40 & 90.91 & 93.1 & [40] \\
\hline Iron nanoparticle & 0.1 & 11 & 10 & & 99 & [41] \\
\hline CdS nanoparticle & 2 & 6 & 15 & 200 & 98 & [42] \\
\hline Rice straw/magnetic nanocomposites & 0.13 & & 1 & 19.45 & 96.25 & [44] \\
\hline Nd-TiO2/bentonite & \multirow{2}{*}{0.3} & \multirow{2}{*}{7} & \multirow{2}{*}{15} & 16.94 & 83 & \multirow{2}{*}{ [45] } \\
\hline Ce-TiO2/bentonite nanocomposites & & & & 17.53 & 80 & \\
\hline $\begin{array}{c}\text { Eleocharis dulcis Fibers }-\mathrm{Fe}_{3} \mathrm{O}_{4} \\
\text { Nanoparticles }\end{array}$ & 2.5 & 6 & 120 & 180.92 & & [46] \\
\hline Nano-silversol-coated activated carbon & 2.5 & 5.5 & 60 & 23.81 & 92.42 & [48] \\
\hline
\end{tabular}

Table 1: Nanoadsorbents used for the removal of Lead in wastewater.

\section{Conclusion}

Recent advances and developments in nanoparticles/nanocomposites as nanoadsorbents have proven to be significant and powerful tool for removal of Lead in wastewater due their unique properties especially high surface area to volume ratio. In this review the following were noted;

Bottum-up synthesis was mostly used in synthesizing the nanoadsorbent than the Top-up method. In fact from this review, top-up method was used by only one researcher in synthesizing the nanoadsorbent.

Most used characterizations techniques for the nanoadsorbents includes; SEM, TEM, FTIR, XRD, TGA and Ultra-violet/visible spectroscopy.

Only batch adsorption method was used by the researchers with no report on column adsorption.

Large scale industrial wastewater treatment was not reported and therefore recommended.

\section{References}

1. Athar M, Vohora SB (2001) Heavy Metals and Environment. New Delhi: New Age International (P) Limited.

2. Musilova J, Arvay J, Vollmannova A, Toth T, Tomas J (2016) Environmental contamination by heavy metals in region with previous mining activity. Bulletin of Environmental Contamination and Toxicology 97(4): 569-575.

3. Radhakrishnan A, Rejani P, Beena B (2015) $\mathrm{CuO} /$ polypyrrole nanocomposites as a marker of toxic lead ions for ecological remediation in contrast with $\mathrm{CuO}$ and polypyrrole. Main Group Met Chem 38(5-6): 133-143.

4. Lee G, Bigham JM, Faure G (2002) Removal of trace metals by coprecipitation with $\mathrm{Fe}, \mathrm{Al}$ and Mn from natural waters contaminated with acid mine drainage in the Ducktown Mining District, Tennessee. Applied Geochemistry 17(5): 569-581.

5. Ventura LMB, Mateus VL, de Almeida ACSL, Wanderley KB, Taira FT, et al. (2017) Chemical composition of fine particles (PM2.5): Water-soluble organic fraction and trace metals. Air Quality, Atmosphere \& Health 10(7): 845-852.

6. Awachat RS, Khope RU (2017) Evaluation of Treatment Strategies by Adsorption for Lead Removal from Aqueous Solution. Der Chemica Sinica 8(6): 487493.

7. Mwangi IW, Ngila JC, Okonkwo JO (2012) A comparative study of modified and unmodified maize tassels for the removal of selected trace metals in contaminated water. Toxicol Environ Chem 94(1): 2039.

8. Gercel O, Gercel HF (2007) Adsorption of lead (II) ions from aqueous solutions by activated carbon prepared from biomass plant material of Euphorbia rigida. Chem Eng J 132(1-3): 289-297.

9. Mahmoud ME, Osman MM, Hafez OF, Hegazi AH, Elmelegy E (2010) Removal and preconcentration of lead (II) and other heavy metals from water by alumina adsorbents developed by surface-adsorbeddithizone. Desalination 251(1-3): 123-130. 


\section{Nanomedicine \& Nanotechnology Open Access}

10. Needleman HL (1999) History of lead poisoning in the world. The George Foundation, Bangalore, India, pp: 17-25.

11. Wilson Lamayi D, Shehu Z, Solomon Kwarson P (2018) Aqueous Phase Removal of Fluoride as Fluorosis agent Using Montmorillonite Clay as a Natural Nanoadsorbent. Nanochemistry Res 3(2): 219-226.

12. Musico YLF, Santos CM, Dalidab MLP, Rodrigues DF (2013) Improved removal of lead(II) from water using a polymer-based graphene oxide nanocomposite. J Mater Chem A 1(11): 3789-3796.

13. Pourjavadi A, Abedin-Moghanaki A, Hosseini SH (2016) Synthesis of poly(amidoamine)-graftpoly(methyl acrylate) magnetic nanocomposite for removal of lead contaminant from aqueous media. Int J Environ Sci Technol 13(10): 2437-2448.

14. Ghogomu JN, Muluh SN, Ajifack DL, Alongamo AAB, Noufame DT (2016) Adsorption of Lead (II) from Aqueous Solution using Activated Carbon Prepared from Raffia Palm (Raphia Hookeri) Fruit Epicarp. IOSR Journal of Applied Chemistry (IOSR-JAC) 7(1): 74-85.

15. Hassan KH, Mahdi ER (2016) Synthesis and Characterization of Copper, Iron Oxide Nanoparticles used to Remove Lead from Aquous Solution. Asian Journal of Applied Sciences 4(3): 730-738.

16. Zadeh SHB, Daghighi M, Torkian L (2019) "Preparation, Characterization, Equilibrium Isotherms, and Adsorption Kinetics of $\mathrm{Al}_{2} \mathrm{O}_{3}-\mathrm{SiO}_{2}$ Nanoparticle for Rapid and High Adsorption of $\mathrm{Pb}$ (II)From Water". International Journal of Pharmaceutical and Phytopharmacological Research 9(1): 51-57.

17. Lasheen MR, Iman YE, Shaimaa TE, Dina YS, El-Shahat MF (2017) Heavy metals removal from aqueous solution using magnetite Dowex 50WX4 resin nanocomposite. Journal of materials and Environmental Sciences 8(2): 503-511.

18. Tawfik AS (2016) Nanocomposite of carbon nanotubes/silica nanoparticles and their use for adsorption of $\mathrm{Pb}(\mathrm{II})$ : from surface properties to sorption mechanism. Desalination and Water Treatment 57(23): 10730-10744.
19. Helal MID, Kahter HA, Marzoog A (2016) Application of Nanotechnology in Remediation of Heavy Metals Polluted Soils. Journal of Arid Land Studies 26(3): 129-137.

20. Le CT, Tan VM, Binh PT (2017) Removal of Pb2+ from aqueous Solution by adsorption onto composite based on Eucalyptus Leaf and Polyaniline. Journal of Science and Technology 55(1): 54-63.

21. Poursani AS, Nilchi A, Hassani A, Shariat SM, Nouri J (2016) The Synthesis of Nano TiO2 and Its Use for Removal of Lead Ions from Aqueous Solution. Journal of Water Resource and Protection 8(4): 438-448.

22. Shiralipour R, Parham H, Zargar B (2015) Removal and Preconcentration of $\mathrm{Pb}$ (II) and Cd (II) by ZeroValent Iron Nanoparticles in Contaminated Water. Jundishapur J Health Sci 7(2): 1-8.

23. Kanchana V, Gomathi T, Geetha V, Sudha PN (2012) Adsorption analysis of $\mathrm{Pb}(\mathrm{II})$ by nanocomposites of chitosan with methyl cellulose and clay. Der Pharmacia Lettre 4 (4): 1071-1079.

24. Sai Krishna YVS, Sandhya G, Babu RR (2018) Removal of Heavy Metals $\mathrm{Pb}$ (II), Cd(II) And Cu(II) From Waste Waters Using Synthesized Chromium Doped Nickel Oxide Nano Particles. Bulletin of the Chemical Society of Ethiopia 32(2): 225-238.

25. Gupta VK, Tyagi I, Sadegh H, Shahryari-Ghoshekandi R, Makhlouf ASH, et al. (2015) Nanoparticles as Adsorbent; A Positive Approach for Removal of Noxious Metal Ions: A Review. Science Technology and Development 34(3): 195-214.

26. Vazquez-Olmos AR, Abatal M, Sato-Berru RY, PedrazaBasulto GK, Garcia-Vazquez V, et al. (2016) Mechanosynthesis of MFe2O4 ( $\mathrm{M}=\mathrm{Co}, \mathrm{Ni}$, and $\mathrm{Zn}$ ) Magnetic Nanoparticles for $\mathrm{Pb}$ Removal from Aqueous Solution. Journal of Nanomaterials 1-9.

27. Charpentier TVJ, Neville A, Lanigan JL, Barker R, Smith MJ, et al. (2016) Preparation of Magnetic Carboxymethylchitosan Nanoparticles for Adsorption of Heavy Metal Ions. ACS Omega 1(1): 77-83.

28. Bhadra J, Al-Thani NJ, Abul Baker AA (2016) Removal of Lead Ions from Aqueous Solutons Using Polyaniline Polystyrene Nanocomposites. Qatar Foundation Annual Research Conference Proceeding 1.
Shehu Z and Lamayi DW. Recent Advances and Developments in Nanoparticles/ Nanocomposites as Nanoadsorbent for Adsorptive Removal of Lead in Wastewater: A Review. Nanomed Nanotechnol 2019, 4(3): 000165. 


\section{Nanomedicine \& Nanotechnology Open Access}

29. Dargahi A, Golestanifar H, Darvishi P, Karami A, Hasan SH, et al. (2016) An Investigation and Comparison of Removing Heavy Metals (Lead and Chromium) from Aqueous Solutions Using Magnesium Oxide Nanoparticles. Pol J Environ Stud 25(2): 557-562.

30. Giraldo L, Erto A, Moreno-Pirajan JC (2013) Magnetite nanoparticles for removal of heavy metals from aqueous solutions: synthesis and characterization. Adsorption 19(2-4): 465-474.

31. Firozjaee TT, Mehrdadi N, Baghdadi M, Bidhendi GRN (2018) Application of Nanotechnology in Pesticides Removal from Aqueous Solutions - A review. Int J Nanosci Nanotechnol 14(1): 43-56.

32. Gupta VR, Tyagi I, Sadegh H, Shahryari-Ghoshekandi R, Makhlouf ASH, Maazinejad B (2015) Nanoparticles as Adsorbent; A Positive Approach for Removal of Noxious Metal Ions: A Review. Science Technology and Development 34 (3): 195-214.

33. Varghese LR, Das N (2015) Application of nanobiocomposites for remediation of heavy metals from aqueous environment : An Overview. International Journal of Chem Tech Research 8(2): 566-571.

34. Gupta VK, Nayak A (2012) Cadmium removal and recovery from aqueous solutions by novel adsorbents prepared from orange peel and $\mathrm{Fe}_{2} \mathrm{O}_{3}$ nanoparticles. Chem Eng J 180(15): 81-90.

35. Mehta K, Sata P, Saraswat A, Mehta D (2018) Nano materials in water purification, Conference of Nanotechnology \& Applications In Civil Engineering2018. International Journal of Advance Engineering and Research Development 5(3): 1-5.

36. Gangadhar G, Maheshwari U, Gupta S (2012) Application of Nanomaterials for the Removal of Pollutants from Effluent Streams. Nanoscience \& Nanotechnology-Asia 2: 140-150.

37. Yadi M, Mostafavi E, Saleh B, Davaran S, Aliyeva I, et al. (2018) Current developments in green synthesis of metallic nanoparticles using plant extracts: A review. Artificial Cells Nanomed Biotechnol 46(3): 336-343.

38. Arole VM, Munde SV (2014) Fabrication of nanomaterials by top-down and bottom-up approaches - an overview. JAAST Material Science 1(2): 89-93.
39. Mishra AK (2015) Nanocomposites in wastewater treatment. Pan Stanford Publishing, pp: 130-133.

40. Shehu Z, Danbature WL, Ahmed M (2017) Adsorption of lead in aqueous solution using Montmorillonitesilica nanocomposite. The Pharmaceutical and Chemical Journal 4(5): 27-34.

41. Han T, Zhang X, Fu X, Liu J (2016) Facile synthesis of chitosan nanoparticle-modified $\mathrm{MnO} 2$ nanoflakes for ultrafast adsorption of $\mathrm{Pb}(\mathrm{II})$ from aqueous solution. Water Science and Technology: Water Supply 17(1): 32-38.

42. Namavari S, Moeinpour F (2016) Use of Aloe vera shell ash supported $\mathrm{Ni} 0.5 \mathrm{Zn} 0.5 \mathrm{Fe} 2 \mathrm{O} 4$ magnetic nanoparticles for removal of $\mathrm{Pb}$ (II) from aqueous solutions. Environmental Health Engineering and Management Journal 3(1): 15-21.

43. Alsouz MAK, Abdullwahid A, Shanshool J, Salim AJ, Najim T, et al. (2016) Evaluation of removal study of $\mathrm{pb}$ (II) from aqueous solution onto polyaniline nanocomposite (prepared in situ by oxidative polymerization of aniline in presence of natural Bentonite). International Journal of Applied Chemistry 12(2): 157-174.

44. Haerizade BN, Ghavami M, Koohi M, Darzi SJ, Rezaee $\mathrm{N}$, et al. (2018) Green Removal of Toxic $\mathrm{Pb}(\mathrm{II})$ from Water by a Novel and Recyclable $\mathrm{Ag} / \gamma-\mathrm{Fe}_{2} \mathrm{O}_{3} @ \mathrm{r}-\mathrm{GO}$ Nanocomposite. Iranian Journal of Chemistry and Chemical Engineering 37(1): 29-37.

45. Moezzi A, Soltanali S, Torabian A, Hasani A (2017) Removal of Lead from Aquatic Solution Using Synthesized Iron Nanoparticles. Int J Nanosci Nanotechnol 13(1): 83-90.

46. Golkhah S, Mousavi HZ, Shirkhanloo H, Khaligh $\mathrm{A}$ (2017) Removal of $\mathrm{Pb}(\mathrm{II})$ and $\mathrm{Cu}(\mathrm{II})$ Ions from Aqueous Solutions by Cadmium SulfideNanoparticles. Int J Nanosci Nanotechnol 13(2): 105-117.

47. Ebadi M, Shagholani H, Jahangiri H (2016) High Efficient Nanocomposite for Removal of Heavy Metals $(\mathrm{Hg} 2+$ and $\mathrm{Pb} 2+)$ from Aqueous Solution. J Nanostruct 6(1): 23-27.

48. Khandanlou R, Ahmad MB, Fard Masoumi HR, Shameli K, Basri M, et al. (2015) Rapid Adsorption of Copper(II) and Lead(II) by Rice Straw $/ \mathrm{Fe}_{3} \mathrm{O}_{4}$ Nanocomposite: Optimization, Equilibrium 


\section{Nanomedicine \& Nanotechnology Open Access}

Isotherms, and Adsorption Kinetics Study. PLoS ONE 10(3): 1-19.

49. Samadi S, Motallebi R, Nasiri NM (2016) Synthesis, characterization and application of Lanthanide metaliondoped $\mathrm{TiO}_{2}$ /bentonite nanocomposite for removal of Lead (II) and Cadmium (II) from aquatic media. J Water Environ Nanotechnol 1(1): 35-44.

50. Irawan C, Nata FI, Putra MD, Ristianingsih Y (2018) Biosorption of Lead (II)-containing Sasirangan Textile Wastewater using Nanocomposites of Eleocharis dulcis Fibers with Iron (III) Nanoparticles as Adsorbent. MATEC Web of Conferences 156: 1-6.

51. Jassal PS, Chand N, Gupta S, Singh R (2015) Harnessing Magnetic Chitosan Nanocomposites for the Adsorption of Heavy-Metal Ions from Aqueous Medium. Journal of Water Resource and Hydraulic Engineering 4(2): 191-197.
52. Kumar PS, Vincent C, Kirthika K, Kumar KS (2010) Kinetics and Equilibrium Studies of $\mathrm{Pb}^{2+}$ Ion Removal from aqueous solutions by use of Nano-SilversolCoated Activated Carbon. Brazilian Journal of Chemical Engineering 27(2): 339-346.

53. Das MP, Rebecca JL (2018) Removal of Lead (II) by Phyto-inspired Iron Oxide Nanoparticles. Nature Environment and Pollution Technology 17(2): 569574.

54. Choudhury PR, MondalP, Majumdar S (2015) Synthesis of bentonite clay based hydroxyapatite nanocomposites cross-linked by glutaraldehyde and optimization by response surface methodology for lead removal from aqueous solution. RSC Advances 5: 100838-100848. 